\section{Jurnal Kimia Sains dan Aplikasi Journal of Scientific and Applied Chemistry}

Journal homepage: http://ejournal.undip.ac.id/index.php/ksa

\title{
Study of Adsorption-Desorption on Batik Industrial Dyes (Naphthol Blue Black) on Magnetite Modified Humic Acid ( $\left.\mathrm{HA}-\mathrm{Fe}_{3} \mathrm{O}_{4}\right)$
}

\author{
Maya Rahmayanti ${ }^{a, 1, *}$, Erni Yunita ${ }^{a, 2}$, Nunung Faizah Yosi Putri ${ }^{\mathrm{a}, 3}$ \\ ${ }^{a}$ Department of Chemistry, Faculty of Science and Technology, Universitas Islam Negeri Sunan Kalijaga, Yogyakarta, Indonesia \\ * Author's email: (1,*)maya.rahmayanti@uin-suka.ac.id; (2)erniyunita859@gmail.com; (3)yosiputri1712@gmail.com
}

https://doi.org/10.14710/jksa.23.7.244-248

\begin{tabular}{l} 
Article Info \\
\hline Article history: \\
Received: $14^{\text {th }}$ April 2020 \\
Revised: $8^{\text {th }}$ July 2020 \\
Accepted: $8^{\text {th }}$ July 2020 \\
Online: $31^{\text {st }}$ July 2020 \\
\hline
\end{tabular}

Keywords: naphthol blueblack; HA$\mathrm{Fe}_{3} \mathrm{O}_{4}$; adsorption; desorption; desorption agent

\begin{abstract}
The rapid development of the batik industry can pollute water resources and become an increasingly severe problem. This research studies the adsorption-desorption of naphthol blue-black (one of the dyes in batik liquid waste) by magnetite modified humic acid $\left(\mathrm{HA}-\mathrm{Fe}_{3} \mathrm{O}_{4}\right.$ ). The adsorption isotherm was studied using the Langmuir and Freundlich isotherm models. Meanwhile, desorption agents used in this study were distilled water and hydrochloric acid. The results show that the adsorption isotherm followed the Langmuir adsorption model with a maximum adsorption capacity of $2.41 \mathrm{mmol} / \mathrm{g}$. Desorption studies show that the desorption efficiency of naphthol blue-black on $\mathrm{HA}-\mathrm{Fe}_{3} \mathrm{O}_{4}$ is $0.058 \%$ and $5.86 \%$ in the desorption agent of distilled water and $\mathrm{HCl}(1 \mathrm{M})$
\end{abstract}

\section{Introduction}

Naphthol blue-black is two typical dyes that are widely used by batik artisans in Indonesia. These dyes are non-biodegradable organic compounds, so it is complicated to degrade in nature. In batik coloring, the dye is only used around 45\%, while the remaining 55\% will be disposed of as liquid waste. The existence of these compounds in nature can cause environmental pollution, especially the aquatic environment. Therefore, it is necessary to process dyes contained in batik liquid waste before batik waste is discharged into the waters.

Currently, wastewater treatment techniques in the batik industry are being developed, including photocatalysis, electrolysis, nanofiltration, ultrafiltration, and adsorption [1, 2, 3, 4]. Photocatalysis and electrolysis methods are less effective because they require high costs and are difficult to apply. Meanwhile, the nanofiltration method can cause new problems because the adsorbed dyes will accumulate on the adsorbent's surface. The adsorption method is reported to be quite useful in removing dyes from batik liquid waste. The advantages of the adsorption method are economical and straightforward. It is just that the dye will accumulate on the surface of the adsorbent and become new waste. Thus, it is necessary to conduct further treatment of the adsorbent post adsorption so that the adsorbent does not become waste and cause new problems.

This study reports the use of economical materials and based on natural resources and local minerals in Indonesia to overcome the naphthol blue-black dyes. The material used in this study is humic acid (HA), which is isolated from peat soils originating from Riau, Sumatra. Humic acid has been widely developed and reported as a successful adsorbent for heavy metals [5, 6, 7] and textile dye compounds [8]. Chemically, HA is a macromolecule that is rich in active groups such as carboxylate $(-\mathrm{COOH})$ and hydroxyl (OH) groups, both phenolics and alcoholates, and quinones $[9,10]$. Hence humic acid is thought to have high absorptivity, including naphthol blue-black dyes. To the author's knowledge, humic acid isolated from Riau's peat soils in Sumatra has not been much studied as an adsorbent for naphthol blue-black dyes. The selection of humic acid from the isolation of peatlands in Riau, Sumatra, is based on Rahmayanti et al. [10], who reported that the humic acid from the isolation 
of Riau peatlands in Sumatra has a higher $-\mathrm{OH}$ group content than humic acid from Kalimantan peatlands.

Humic acid has stability at low $\mathrm{pH}(\mathrm{pH}<3)$ and dissolves at $\mathrm{pH}>3$ [9] so that the $\mathrm{pH}$ range of adsorption is limited. HA coating on magnetite compounds $\left(\mathrm{Fe}_{3} \mathrm{O}_{4}\right)$ can be done so that HA, as an adsorbent, can work over a wider $\mathrm{pH}$ range. Another benefit of $\mathrm{AH}$ coating on magnetite compounds is that the desorption process can be carried out without filtration and centrifugation because separation can use external magnetic fields to be more environmentally friendly $[11,12]$. The coating on $\mathrm{Fe}_{3} \mathrm{O}_{4}$ is expected to reduce the particle size of the adsorbent produced so that it can increase the adsorption ability of naphthol blue-black dyes.

\section{Methodology}

\subsection{Equipment and Materials}

In this study, the humic acid was humic acid from the isolation of peat soils in Riau, Sumatra. The humic acid coating on magnetite was carried out using iron chloride hexahydrate $\left(\mathrm{FeCl}_{3} \cdot 6 \mathrm{H}_{2} \mathrm{O}\right)$, iron sulfate hexahydrate $\left(\mathrm{FeSO}_{4 .} \cdot 7 \mathrm{H}_{2} \mathrm{O}\right)$ and sodium hydroxide. The desorption agents used were distilled water and hydrochloric acid. All of these chemicals came from Merck Darmstadt, Germany. The naphthol blue-black dye used was special in the batik industry.

The equipment used in this study was a set of standard laboratory glassware, vacuum pumps, 4800 Thermolyne oven/furnace, BP 110 Sartorius analytical balance, desiccator, Leistungsfreq type sonicator, 70VA generator, Orion 920A pH meter, shaker (Osk), Shimadzu-8201 PC Fourier Transform Infrared (FTIR) spectrophotometer, and Double Beam 1601 PC Shimadzu UV-VIS Spectrophotometer.

\subsection{Preparation of magnetite-modified humic acid}

$\left(\mathrm{HA}-\mathrm{Fe}_{3} \mathrm{O}_{4}\right)$

The magnetite modified humic acid preparation was carried out following the method of Rahmayanti et al. [6] with a slight change. $5.56 \mathrm{~g}(0.01 \mathrm{~mol})$ of $\mathrm{FeSO}_{4.7} \cdot \mathrm{H}_{2} \mathrm{O}$ was dissolved in $200 \mathrm{~mL}$ of distilled water and added to $11.12 \mathrm{~g}$ ( 0.02 mole) of $\mathrm{FeCl}_{3} .6 \mathrm{H}_{2} \mathrm{O}$, which was dissolved in $200 \mathrm{~mL}$ of distilled water. The solution was heated at $90^{\circ} \mathrm{C}$ while stirring, then the mixture was added to the $\mathrm{NaOH}$ solution set at a pH of 13 and then added with $2 \mathrm{~g}$ of humic acid resulting from the isolation of peat soils. The mixture was stirred at $90^{\circ} \mathrm{C}$ for 60 minutes. Then the mixture was allowed to stand at the same temperature for 60 minutes. The mixture was cooled at room temperature, then filtered, and the precipitate obtained was washed with 100 $\mathrm{mL}$ of distilled water six times (with the help of an external magnetic field). Washing precipitates were heated using an oven at $90^{\circ} \mathrm{C}$ then characterized using XRD and FTIR spectrophotometers.

\subsection{Absorption of naphthol blue-black on $\mathrm{HA}-\mathrm{Fe}_{3} \mathrm{O}_{4}$}

Ten mg of $\mathrm{HA}-\mathrm{Fe}_{3} \mathrm{O}_{4}$ was mixed with $10 \mathrm{~mL}$ of naphthol blue-black dye solution at $\mathrm{pH} 2$ with varying concentrations of $100,200,300,400$, and $500 \mathrm{ppm}$. The mixture was shaken for 60 minutes then filtered using Whatman filter paper (with the help of an external magnetic field at the bottom of the bottle). The filtrate obtained was then measured for $\mathrm{pH}$, then analyzed using a UV-Vis spectrophotometer.

\subsection{Study of adsorption isotherms}

The adsorption isotherm models used to explain the pattern of adsorption isotherms in this study are Langmuir and Freundlich isotherm models. The Langmuir adsorption isotherm model can be expressed by equation (1).

$$
\frac{C_{e}}{q_{e}}=\frac{1}{q_{\max } K_{L}}+\frac{C_{e}}{q_{\max }}
$$

The amount of metal adsorbed at the equilibrium state $(\mathrm{mg} / \mathrm{g})$ is expressed as $q_{\mathrm{e}} \mathrm{C}_{\mathrm{e}}$ is the concentration of free metal ions in solution at equilibrium $(\mathrm{mg} / \mathrm{L})$. $\mathrm{q}_{\max }$ is the maximum adsorption capacity ( $\mathrm{mg} / \mathrm{g})$, and $\mathrm{KL}$ is the Langmuir constant $(\mathrm{L} / \mathrm{mol})$ related to the adsorption energy [13].

The Freundlich isotherm model is expressed by equation (2).

$$
\log q_{e}=\log K F+\frac{1}{n} \log C_{e}
$$

The number of species adsorbed per gram of adsorbent at equilibrium ( $\mathrm{mg} / \mathrm{g}$ ) is referred to as $q_{\mathrm{e}} . C_{\mathrm{e}}$ is the concentration of free metal ions in solution at a state of equilibrium capacity $(\mathrm{mg} / \mathrm{g}) . \mathrm{KF}$ is the Freundlich constant, which is related to adsorption capacity, and $1 / n$ is a factor of heterogeneity [14].

\subsection{Desorption of Naphthol Blue Black Dyes}

The post-adsorption $\mathrm{HA}-\mathrm{Fe}_{3} \mathrm{O}_{4}$ adsorbent was put into distilled water and added by $\mathrm{HCl}$ desorption agent with a variation of $0.5 \mathrm{M} ; 1 \mathrm{M} ; 1.5 \mathrm{M}$, and $2 \mathrm{M}$. The mixture was shaken at $125 \mathrm{rpm}$ for 60 minutes. The solution was filtered for the filtrate then analyzed using a UV-Vis spectrophotometer according to the naphthol blue-black dye wavenumber. Post desorption adsorbents were characterized using FTIR. The percentage of desorption was calculated using the formula presented in Equation 3.

$\frac{\text { naphthol blue-black dye }{ }_{\text {initial }} \text {-naphthol blue-black dye } \text { remain }^{\text {nat }}}{\text { naphthol blue-black dye } \text { initial }} \times 100 \%$

\section{Results and Discussion}

\subsection{Modification of Humic Acid with Magnetite (HA- $\mathrm{Fe}_{3} \mathrm{O}_{4}$ )}

The success of modification of humic acid with $\mathrm{Fe}_{3} \mathrm{O}_{4}$ was studied using FTIR, and the spectra are presented in Figure 1. The presence of magnetite in humic acid is characterized by absorption at a wavelength of $580 \mathrm{~cm}^{-1}$, which is the stretching vibration of Fe-O. Meanwhile, the 
loss of absorption of the carboxylic group $\mathrm{C}=\mathrm{O}$ at wavelengths of $1700 \mathrm{~cm}^{-1}$ and $1500 \mathrm{~cm}^{-1}$ indicates that the organic compound's anion binds to the surface of the magnetite through chemical bonds. The possibility is through a carboxylic group that is symmetrically bonded to the magnetite surface, as indicated by the absorption only in the region of $1400 \mathrm{~cm}^{-1}$. Absorption, which shows functional groups of HA, also appears (Figure 1. (c)) even with lower intensity. Thus, it can be said that the modification of humic acid with $\mathrm{Fe}_{3} \mathrm{O}_{4}$ has been successfully carried out. Evidence of $\mathrm{HA}-\mathrm{Fe}_{3} \mathrm{O}_{4}$ adsorbent having magnetic properties is presented in Figure 2. (a).

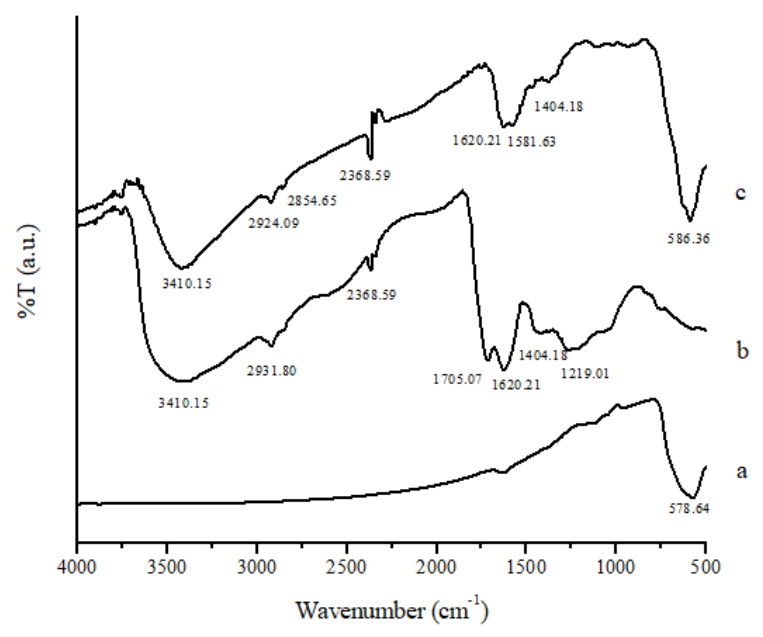

Figure 1. FTIR spectra (a). $\mathrm{Fe}_{3} \mathrm{O}_{4}$; (b) $\mathrm{HA}$; (c) $\mathrm{HA}-\mathrm{Fe}_{3} \mathrm{O}_{4}$
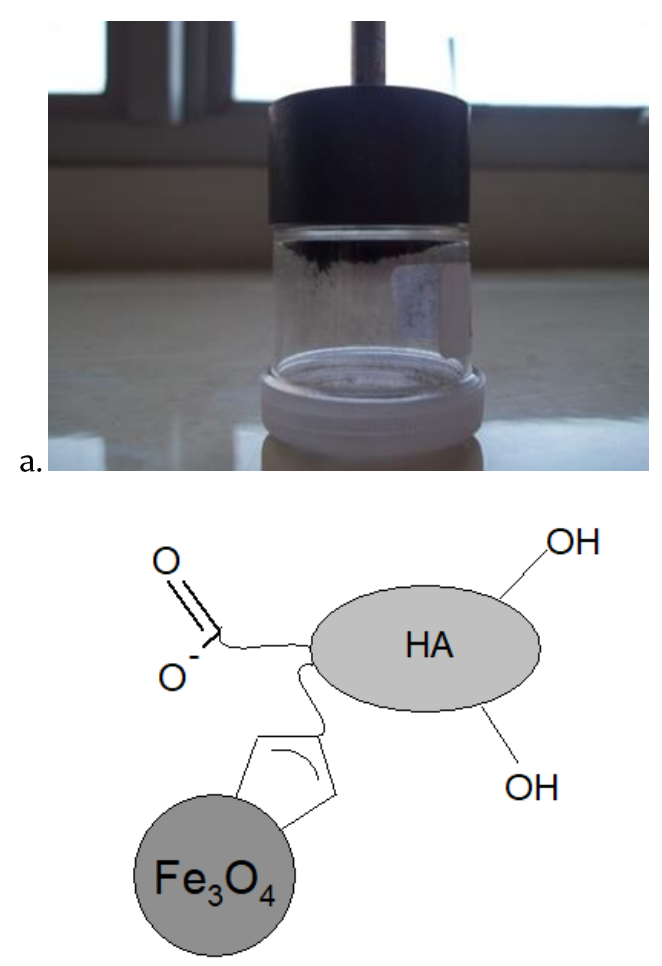

b.

Figure 2. (a). The $\mathrm{HA}-\mathrm{Fe}_{3} \mathrm{O}_{4}$ adsorbent is attracted by the external magnetic field (b). Illustration of interaction between magnetite and humic acid through the formation of chelate - $\mathrm{COO}-\mathrm{Fe}$
The alleged interaction between $\mathrm{Fe}_{3} \mathrm{O}_{4}$ and $\mathrm{HA}$ is through the formation of chelate - $\mathrm{COO}-\mathrm{Fe}$ (Figure 2) because the modification of $\mathrm{HA}$ with $\mathrm{Fe}_{3} \mathrm{O}_{4}$ is carried out in an alkaline atmosphere ( $\mathrm{pH} 9-10)$. In this condition, the surface of $\mathrm{Fe}_{3} \mathrm{O}_{4}$ tends to be negative because the $\mathrm{pH}>$ point of zero charges ( $\mathrm{pHpzc}$ ) of $\mathrm{Fe}_{3} \mathrm{O}_{4}$. Meanwhile, at this $\mathrm{pH}$, the carboxylic and phenolate $\mathrm{HA}$ groups have been deprotonated so that interaction between the $\mathrm{Fe}_{3} \mathrm{O}_{4}$ surface with - $\mathrm{COO}-$ and -O- is not possible to occur through electrostatic interactions.

\subsection{Study of Naphthol Blue Black Adsorption Isotherms on $\mathrm{HA}-\mathrm{Fe}_{3} \mathrm{O}_{4}$}

In this study, the naphthol blue-black adsorption isotherm on $\mathrm{HA}-\mathrm{Fe}_{3} \mathrm{O}_{4}$ was studied through the Langmuir and Freundlich adsorption isotherm models. The Langmuir adsorption isotherm model was determined by making a graph of $C_{\mathrm{e}} / q_{\mathrm{e}}$ versus $C_{\mathrm{e}}$, as presented in Figure 3b. Based on the graph, on the naphthol blue-black adsorption on $\mathrm{HA}-\mathrm{Fe}_{3} \mathrm{O}_{4}$, the correlation coefficient $\left(\mathrm{R}^{2}\right)$ obtained is 0.996 , an adsorption capacity of $0.00241 \mathrm{~mol}$ $\mathrm{g}^{-1}$ adsorbent, adsorption equilibrium constant (KL) of 5.9 $\mathrm{x}^{4} \mathrm{~L} \mathrm{~mol}^{-1}$ and adsorption energy $\left(\mathrm{E}_{\mathrm{ads}}=26.64 \mathrm{~kJ} \mathrm{~mol}^{-1}\right)$. Whereas, the Freundlich isotherm model for naphthol blue-black adsorption on $\mathrm{HA}-\mathrm{Fe}_{3} \mathrm{O}_{4}$ was determined by graphing $\log q_{\mathrm{e}}$ versus $\log C_{\mathrm{e}}$, as presented in Figure 3a. Based on the graph, the correlation coefficient $\left(\mathrm{R}^{2}\right)$ obtained is 0.906 , and the Freundlich (KF) constant is $5.77 \times 10^{-2} \mathrm{~mol} \mathrm{~g}^{-1}$.
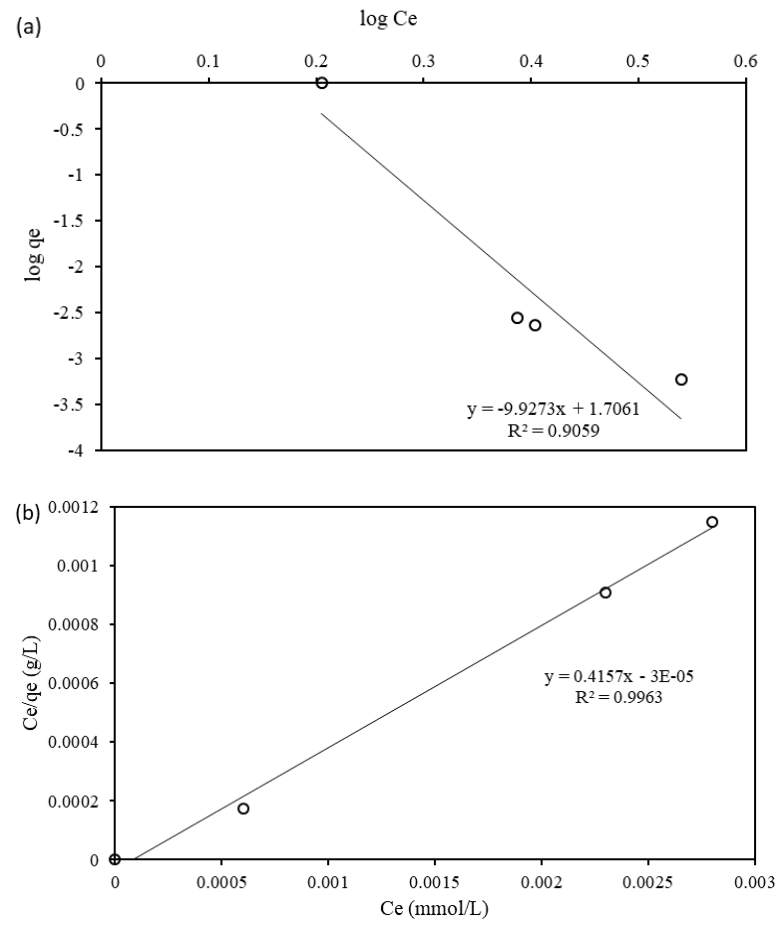

Figure 3. Isotherm adsorption of Naphthol Blue Black on $\mathrm{HA}-\mathrm{Fe}_{3} \mathrm{O}_{4}$ which is fitted to the (a) Freundlich equation and (b) Langmuir equation; (adsorbent dose $0.01 \mathrm{~g}$, reaction time $15 \mathrm{~min}$, reaction temperature $30^{\circ} \mathrm{C}, \mathrm{pH}$ 2.0)

From Table 2, it can be seen that the adsorption of naphthol blue-black on $\mathrm{HA}-\mathrm{Fe}_{3} \mathrm{O}_{4}$ follows the Langmuir 
isotherm model with a correlation coefficient $\left(\mathrm{R}^{2}\right)$ of 0.996. Thus, the active site on the surface of $\mathrm{HA}-\mathrm{Fe}_{3} \mathrm{O}_{4}$ can be considered homogeneous. There is no interaction between naphthol blue-black molecules, so it can be said that naphthol blue-black on $\mathrm{HA}-\mathrm{Fe}_{3} \mathrm{O}_{4}$ only forms one layer (monolayer). When viewed from the adsorption energy $\left(E_{\text {ads }}=26.64 \mathrm{~kJ} / \mathrm{mol}\right)$, the interaction between naphthol blue-black and $\mathrm{HA}-\mathrm{Fe}_{3} \mathrm{O}_{4}$ adsorbent is physisorption. The activation energy in physisorption is in the range of $5-40 \mathrm{~kJ} / \mathrm{mol}$, while chemisorption is $40-$ $800 \mathrm{~kJ} / \mathrm{mol}$ [15]. Compared with some of the results of previous studies (Table 2), it appears that naphthol blueblack dyes can be better adsorbed on $\mathrm{HA}-\mathrm{Fe}_{3} \mathrm{O}_{4}$ compared to methylene blue and gold dyes in aqueous solutions.

Table 2. Calculated values of parameters in Langmuir and Freundlich equations

\begin{tabular}{|c|c|c|c|c|c|c|c|c|}
\hline \multirow[b]{2}{*}{ 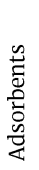 } & \multirow[b]{2}{*}{ 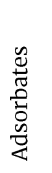 } & \multicolumn{4}{|c|}{ Langmuir equation } & \multicolumn{3}{|c|}{ Freundlich equation } \\
\hline & & 危 & $\underset{\underbrace{}}{\stackrel{\vec{\partial}}{\Xi}}$ & 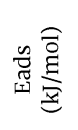 & $\mathrm{R}^{2}$ & 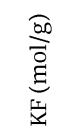 & $\mathrm{n}$ & $\mathrm{R}^{2}$ \\
\hline
\end{tabular}

\begin{tabular}{ccccccccc}
\hline $\mathrm{HA}^{-\mathrm{Fe}_{3} \mathrm{O}_{4}}$ & $\begin{array}{c}\text { Naphthol } \\
\text { Blue Black }\end{array}$ & \begin{tabular}{c}
0.00241 \\
\multicolumn{7}{c}{$\begin{array}{c}5.9 \times \\
10^{4}\end{array}$}
\end{tabular} & 26.64 & 0.996 & 0.0577 & -0.101 & 0.906 \\
\hline $\begin{array}{c}\mathrm{HA}-\mathrm{Fe}_{3} \mathrm{O}_{4} \\
{[6]}\end{array}$ & $\mathrm{HAuCl}_{4}$ & 0.00062 & 1608 & 18.6 & 0.992 & $1.02 \times$ & 4.695 & 0.956 \\
$10^{-4}$ & & \\
\hline $\begin{array}{c}\mathrm{HA}-\mathrm{Fe}_{3} \mathrm{O}_{4} \\
{[14]}\end{array}$ & $\begin{array}{c}\text { Methylene } \\
\text { blue }\end{array}$ & 0.00034 & - & - & 0.997 & - & - & - \\
\hline
\end{tabular}

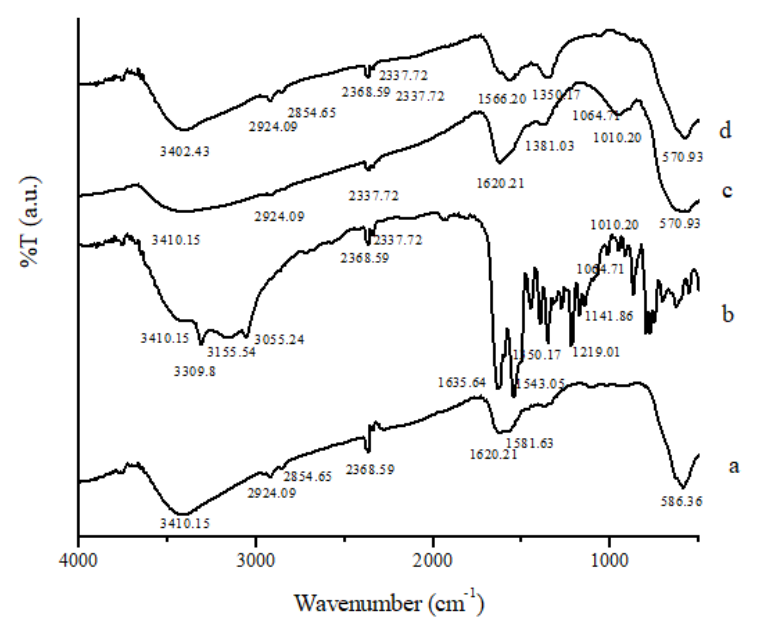

Figure 4. FTIR spectra (a). $\mathrm{HA}-\mathrm{Fe}_{3} \mathrm{O}_{4}$; (b) naphthol blue black (c) $\mathrm{HA}-\mathrm{Fe}_{3} \mathrm{O}_{4}$ after adsorption; (d) $\mathrm{HA}-\mathrm{Fe}_{3} \mathrm{O}_{4}$ after desorption

FTIR data after adsorption (Figure 4) shows that there are differences in uptake that appear before and after naphthol blue-black is adsorbed on $\mathrm{HA}-\mathrm{Fe}_{3} \mathrm{O}_{4}$. The difference is seen in the absorption that appears in the region of $3500-3200 \mathrm{~cm}^{-1}$ and the region of $1000-1100$ $\mathrm{cm}^{-1}$ (Figure $4 \mathrm{c}$ ). The absorption that appears in the area of $3400 \mathrm{~cm}^{-1}$ has decreased intensity after adsorption. This is presumed because the $\mathrm{HA}-\mathrm{Fe}_{3} \mathrm{O}_{4}$ phenolate group plays a role in the naphthol blue-black adsorption process on $\mathrm{HA}-\mathrm{Fe}_{3} \mathrm{O}_{4}$. Interactions that occur are suspected through electrostatic interactions because the adsorption of naphthol blue-black on $\mathrm{HA}-\mathrm{Fe}_{3} \mathrm{O}_{4}$ is carried out at $\mathrm{pH} 2$.
At this $\mathrm{pH}$, the phenolate $-\mathrm{OH}$ group protonates to $-\mathrm{OH}_{2}{ }^{+}$, while the naphthol blue-black group is anionic because it has a $-\mathrm{SO}_{3}{ }^{-}$group, so that electrostatic interactions between the adsorbent surfaces and the adsorbate are possible. The second suspicion, interactions occur through hydrogen bonds between the hydrogen atom of the $-\mathrm{OH}$ phenolate adsorbent group and the oxygen atom of the naphthol blue-black sulfonate group. The appearance of uptake in the $1010 \mathrm{~cm}^{-1}$ and $1066 \mathrm{~cm}^{-1}$ regions (Figure $4 \mathrm{c}$ ) shows the $\mathrm{S}-\mathrm{O}$ group stretch vibrations and the asymmetric strain $\mathrm{S}=\mathrm{O}$ groups originating from the sulfonate groups.

\subsection{Desorption Study on Naphthol Blue Black Dyes}

Desorption studies can be studied using thermal and chemical regeneration methods [16]. In this study, the desorption of naphthol blue-black from $\mathrm{HA}-\mathrm{Fe}_{3} \mathrm{O}_{4}$ adsorbent was studied using chemical methods with desorption agents as distilled water and $\mathrm{HCl}$. The mechanism of the naphthol blue-black (adsorbate) desorption reaction from $\mathrm{HA}-\mathrm{Fe}_{3} \mathrm{O}_{4}$ (adsorbent) using an $\mathrm{HCl}$ desorption agent is thought to be through an ion exchange reaction. The $\mathrm{HCl}$ desorption agent in the solution ionized into $\mathrm{H}^{+}$and $\mathrm{Cl}^{-}$. The $\mathrm{Cl}^{-}$ion replaces the adsorbate (which is negatively charged) to bind to the adsorbent, and or the $\mathrm{H}^{+}$ion replaces the protonated adsorbate (positively charged) to bind to the adsorbate.

Figure 4 shows that the distilled water desorption agent only succeeded in absorbing naphthol blue-black by $0.058 \%$. Meanwhile, the $\mathrm{HCl}$ desorption agent succeeded in absorbing the optimum naphthol blue-black at $5.86 \%$ at $1 \mathrm{M} \mathrm{HCl}$ concentration. Figure 4 shows that if the concentration of $\mathrm{HCl}>1 \mathrm{M}$, desorption decreases. This is presumably because the naphthol blue-black dye is damaged in a solution that is too acidic. The low ability of distilled water and $\mathrm{HCl}$ in the absorption of naphthol blue-black from $\mathrm{HA}-\mathrm{Fe}_{3} \mathrm{O}_{4}$ is suspected because $\mathrm{HCl}\left(\mathrm{H}^{+}\right.$ and $\mathrm{Cl}^{-}$ions) do not sufficiently break the bonds formed between naphthol blue-black and the surface of the adsorbent $\mathrm{HA}-\mathrm{Fe}_{3} \mathrm{O}_{4}$. As previously explained, the bond energy formed between naphthol blue-black and the surface of the $\mathrm{HA}-\mathrm{Fe}_{3} \mathrm{O}_{4}$ adsorbent is $26.64 \mathrm{~kJ} \mathrm{~mol}^{-1}$.

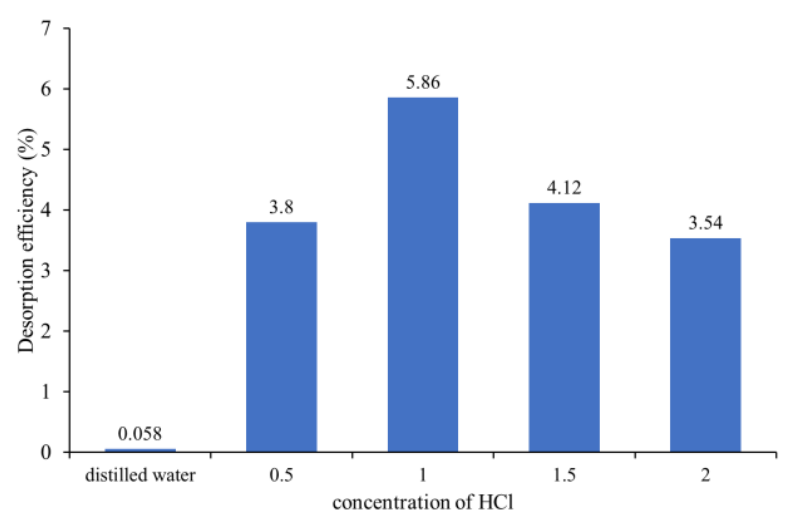

Figure 4. The effect of $\mathrm{HCl}$ concentration on desorption efficiency (reaction time $60 \mathrm{~min}$, reaction temperature $\left.30^{\circ} \mathrm{C}\right)$ 


\section{Conclusions}

Magnetic modified humic acid $\left(\mathrm{HA}-\mathrm{Fe}_{3} \mathrm{O}_{4}\right)$ can be used as an adsorbent for dyes in the batik industry liquid waste (naphthol blue-black). The adsorption isotherm study showed that the adsorption of naphthol blue-black on $\mathrm{HA}-\mathrm{Fe}_{3} \mathrm{O}_{4}$ followed the Langmuir isotherm model with adsorption capacity $\left(q_{\max }\right)=0.00241 \mathrm{~mol} / \mathrm{g}$. Desorption studies show that naphthol blue-black does not succeed in deporting well enough from $\mathrm{HA}-\mathrm{Fe}_{3} \mathrm{O}_{4}$. The efficiency of desorption using distilled water desorption agents is $0.058 \%$ while using $\mathrm{HCl}$ desorption agents $(1 \mathrm{M})$ is $5.86 \%$.

\section{Acknowledgement}

The authors thank to Chemistry Laboratory of Universitas Islam Negeri Sunan Kalijaga for the facilities and services provided.

\section{References}

[1] Payam Moradi Birgani, Navid Ranjbar, Rosniah Che Abdullah, Kien Tiek Wong, Gooyong Lee, Shaliza Ibrahim, Chulhwan Park, Yeomin Yoon, Min Jang, An efficient and economical treatment for batik textile wastewater containing high levels of silicate and organic pollutants using a sequential process of acidification, magnesium oxide, and palm shellbased activated carbon application, Journal of Environmental Management, 184, (2016), 229-239 https://doi.org/10.1016/j.jenvman.2016.09.066

[2] Saidah Malihah Binti Mansor, Batik wastewater treatment using membrane bioreactor (MBR), undergraduate thesis, Faculty of Civil Engineering and Earth Resources, Universiti Malaysia Pahang, Pahang, Malaysia

[3] Tri Murniati, Inayati Inayati, Sri Budiastuti, Pengelolaan Limbah Cair Industri Batik dengan Metode Elektrolisis sebagai Upaya Penurunan Tingkat Konsentrasi Logam Berat di Sungai Jenes, Laweyan, Surakarta, Ekosains, 7, 1, (2015), 77-83

[4] Sushanta Debnath, Niladri Ballav, Hlengilizwe Nyoni, Arjun Maity, Kriveshini Pillay, Optimization and mechanism elucidation of the catalytic photodegradation of the dyes Eosin Yellow (EY) and Naphthol blue black (NBB) by a polyaniline-coated titanium dioxide nanocomposite, Applied Catalysis B: Environmental, 163, (2015), 330-342 https://doi.org/10.1016/j.apcatb.2014.08.011

[5] Fande Meng, Guodong Yuan, Steven L. Larson, John H. Ballard, Charles A. Waggoner, Zikri Arslan, Fengxiang X. Han, Removing Uranium (VI) from Aqueous Solution with Insoluble Humic Acid Derived from Leonardite, Journal of Environmental Radioactivity, 180, (2017), 1-8

https://doi.org/10.1016/j.jenvrad.2017.09.019

[6] Maya Rahmayanti, Guliston Abdillah, Sri Juari Santosa, Sutarno Sutarno, Application of Humic Acid Isolated From Kalimatan Peat Soil Modifying Magnetite for Recovery of Gold, Jurnal Bahan Alam Terbarukan, 8, 2, (2020), 77-83

https://doi.org/10.15294/jbat.v8i2.20392

[7] Syarifatul Muniroh, Maya Rahmayanti, Kinetika Adsorpsi Kromium (VI) yang Terkandung dalam
Limbah Batik pada Asam Humat Termodifikasi Magnetit $\left(\mathrm{AH}-\mathrm{Fe}_{3} \mathrm{O}_{4}\right)$, Integrated Lab Journal, 7, 2, (2019), 42-46

[8] Gita Citra Santi, Maya Rahmayanti, Effect of Solution $\mathrm{pH}$ to Indigosol Blue Adsorption on Humic Acid Isolated from Kalimantan Peat Oil, Proceeding International Conference on Science and Engineering, Yogyakarta, (2019)

[9] George R. Aiken, Diene M. McKnight, Robert L. Wershaw, Patrick MacCarthy, Humic Substances in Soil, Sediment, and Water: Geochemistry, Isolation, and Characterization, Krieger Publishing Company, 1991

[10] Maya Rahmayanti, Erni Yunita, Masyithah Nisvi Prandini, Isolasi Asam Humat dari Tanah Gambut Sumatera dan Kalimantan dan Analisis Kandungan Gugus Fungsionalnya, Integrated Lab Journal, 7, 2, (2019), 132-139

[11] Maya Rahmayanti, Sri Juari Santosa, Sutarno Sutarno, Comparative Study on the Adsorption of $\left[\mathrm{AuCl}_{4}\right]^{-}$onto Salicylic Acid and Gallic Acid Modified Magnetite Particles, Indonesian Journal of Chemistry, $16,3,(2016), 329-337$ https://doi.org/10.22146/ijc.21150

[12] Maya Rahmayanti, Sri Juari Santosa, Sutarno, Sonochemical Co-Precipitation Synthesis of Gallic Acid-Modified Magnetite, Advanced Materials Research, 1101, (2015), 286-289

https://doi.org/10.4028/www.scientific.net/AMR.1101.286

[13] Irving Langmuir, The Constitution and Fundamental Properties of Solids and Liquids. Part I. Solids, Journal of the American Chemical Society, 38, 11, (1916), 22212295 https://doi.org/10.1021/ja02268a002

[14] Herbert Freundlich, Über die Adsorption in Lösungen, Zeitschrift für Physikalische Chemie, 57U, 1, (1907), 385-470 https://doi.org/10.1515/zpch-1907-5723

[15] Stavros G. Poulopoulos, Vassilis J. Inglezakis, Adsorption, Ion Exchange and Catalysis: Design of Operations and Environmental Applications, Elsevier Science, 2006

[16] Liang Peng, Pufeng Qin, Ming Lei, Qingru Zeng, Huijuan Song, Jiao Yang, Jihai Shao, Bohan Liao, Jidong $\mathrm{Gu}$, Modifying $\mathrm{Fe}_{3} \mathrm{O}_{4}$ nanoparticles with humic acid for removal of Rhodamine B in water, Journal of Hazardous Materials, 209-210, (2012), 193-198 https://doi.org/10.1016/j.jhazmat.2012.01.011 